\title{
9. Thirty years of urban policy in Portugal: challenges and multilevel governance
}

\author{
Filipe Teles, Patrícia Romeiro and Sara \\ Moreno Pires
}

\section{INTRODUCTION}

The Portuguese urban context has changed significantly over the past 45 years, facing several transformations that have affected national urban policies. Even following a certain Europeanization of urban policies, most of the urban scenario remains today without a sufficient scale and structure to ensure what we can call a strong national policy corpus to tackle urban sustainability challenges. The socioeconomic vitality of coastal cities still contrasts with the lethargy of smaller cities with lower demographic density in the country's interior (Fernandes and Seixas 2018). The Portuguese local government system constitutes one of only two tiers of government. Besides national government, the Portuguese Constitution only recognizes local autonomous government as being part of its unitary and decentralized state. At the local level, municipalities and civil parishes - both with elected bodies and political and administrative autonomy - have the same constitutional competencies, with no variance arising to reflect the different levels of urbanization in different territories. In fact, most municipalities consist of both urban and rural areas, with the exception of highly urbanized and densely populated parts in the core of the two metropolitan areas of Lisbon and Porto. These two characteristics namely the 'rurban' territory of a significant number of them and the fact that all municipalities have similar responsibilities, structures and competencies are rather important for understanding the features of urban policy in Portugal. The archipelagos of the Azores and Madeira are an exception to this governance landscape, since both have regional autonomy and regional governments as a result of their special geography. All the continental territory of Portugal, therefore, is covered by only two tiers of local self-government, central and local, with the local government tier itself consisting of two levels: the munic- 
ipalities and their sub-municipal units, that is, the civil parishes (with very few competencies and recently reformed) (Tavares and Teles 2018). Against this institutional background, this chapter intends to look at the major old and new urban challenges that have provided the substance for specific national policies towards urban spaces in what is a centralized country.

After this introduction, the second section identifies and discusses these challenges during the 45 years since 1975. The subsequent section details specific policies designed mostly under the influence of the European Union (EU). Section four provides a critical overview of the challenges to multilevel governance of urban policies in the country. The last section presents some concluding remarks.

\section{MAJOR OLD AND NEW URBAN CHALLENGES}

Between 1960 and 2017, Portugal faced numerous demographic changes:

1. Relatively small population growth: from 1960 to 2017 the population grew 15.6 per cent, from 8889392 to 10276617 residents (INE 2019).

2. Mass population migration towards the coast: it promoted an asymmetric territorial distribution of the population and unbalanced demographic dynamics. This massive rural migration to cities, that now accommodate 62 per cent of the population (2011), led to an intensive urban sprawl and the depopulation of many territories in the interior of the country.

3. Periods of strong emigration flows: for instance, the early 1970s saw the highest absolute values of net emigration in the history of Portugal, only comparable to the most recent period of 2011 to 2014.

4. A high and continuous increase in life expectancy at birth, average life expectancy and percentage of population with higher education.

The most relevant trends (see Table 9.1) are somewhat consistent with European demographic and social trends, although in some cases these are expressed more strongly in Portugal. The inversion of the age pyramid in the last decade is a good example of that, with the country having the third oldest population among the $28 \mathrm{EU}$ countries in 2018 (PORDATA 2018), but other examples include the alleviation of poverty, the general improvement in access to education and health services, health and social protection for all, and the increase in the purchasing power of the population (Fernandes and Seixas 2018).

In 1976, the first democratic Constitution expanded the civic, social, cultural and political rights of citizens and pointed to the creation of the National Health Service (in 1979). The 1980s was a period of strong political stability with major macroeconomic efforts being made by the state to fulfil the con- 


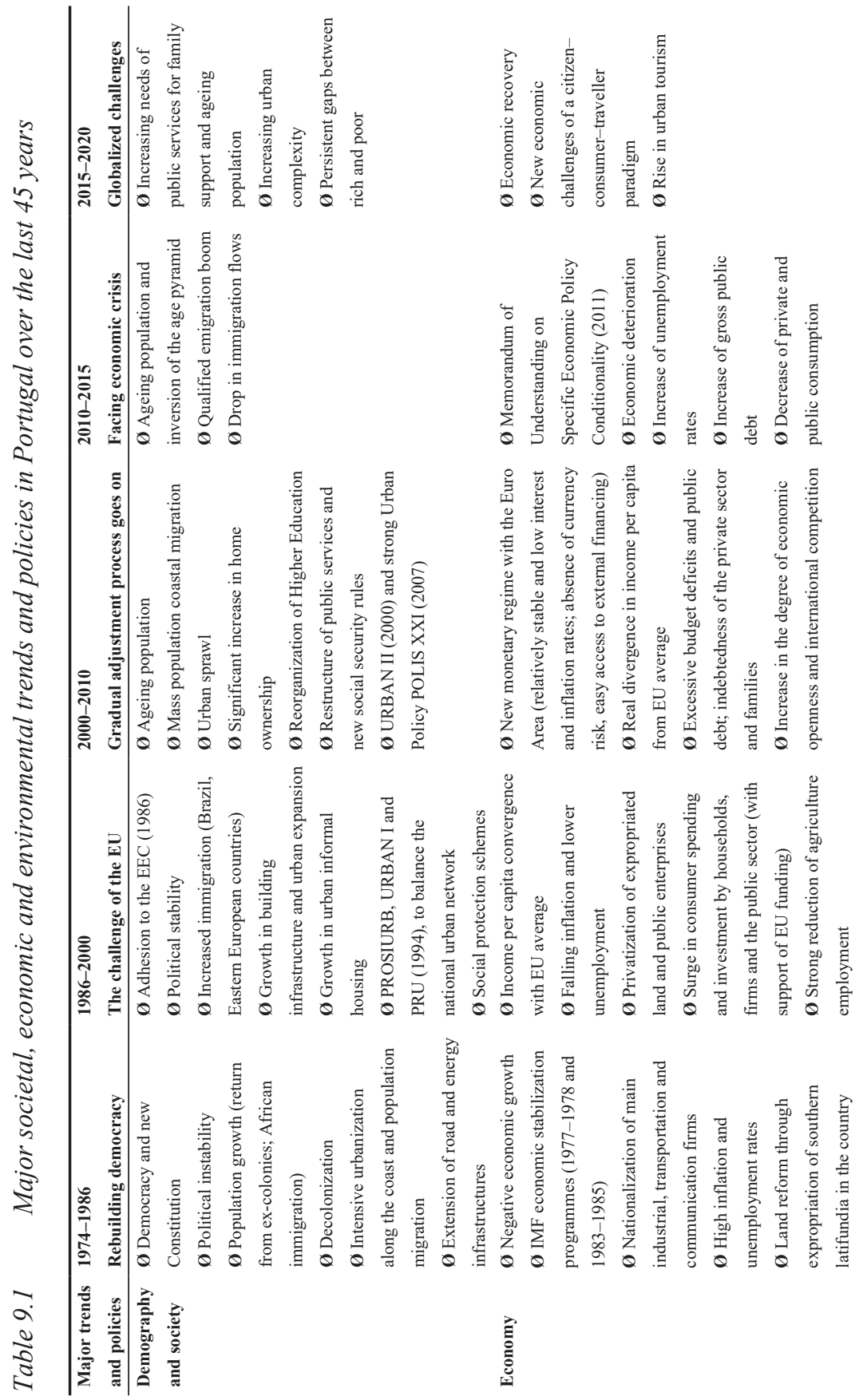




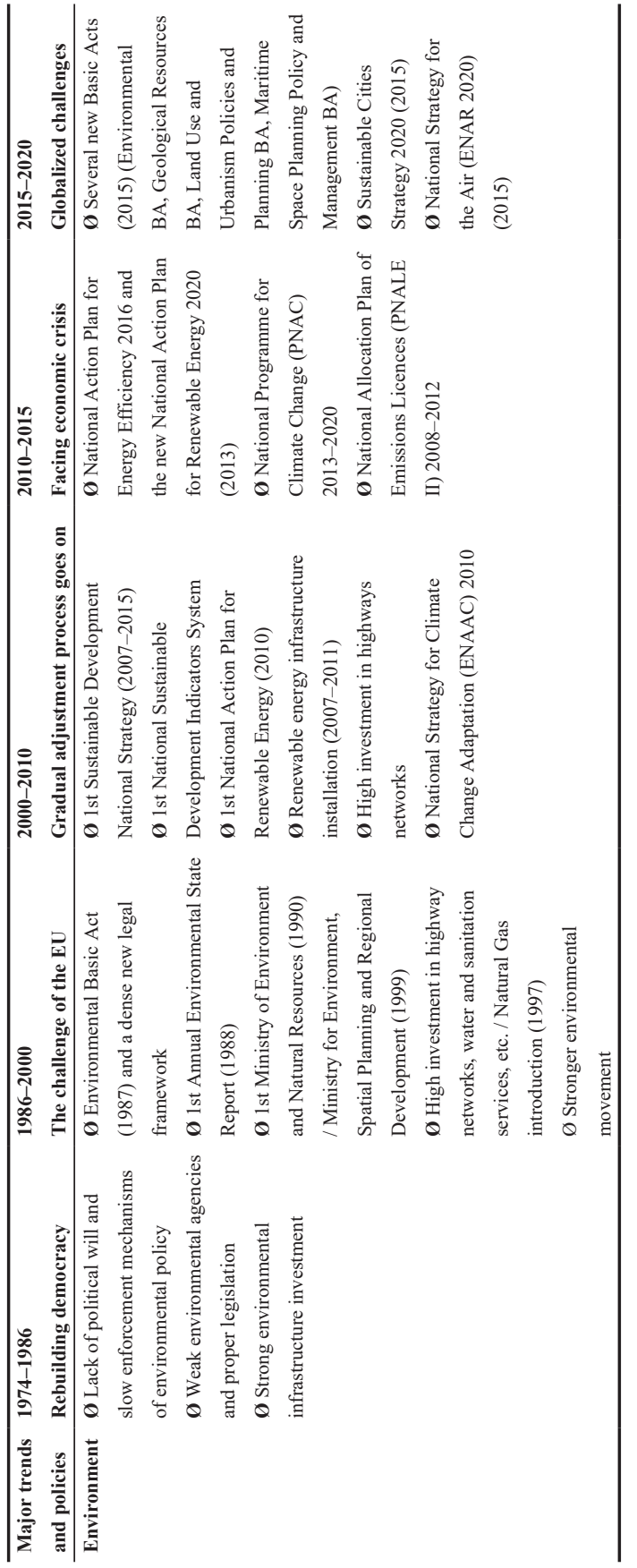


ditions for entering the European Economic Community (EEC). Over the two following decades, Portugal witnessed an enormous urban expansion and with it fragmentation and infrastructure growth. Urban growth associated with suburbanization processes contributed to side effects, such as the emptying and devitalizing of urban central areas, the growth of urban informal housing markets and informal settlements, the exacerbation of pressures on rural areas and land uses, and the increasing of urban poverty and social exclusion (Sá Marques 2006; Cavaco et al. 2016).

Citing a 1993 study, Portas, Domingues and Guimarães refer to Portugal as the 'Archipelago-country' to emphasize its territorial fragmentation, with "metropolitan areas; large "islands", where the territory is characterized by diffuse urbanization and industrialization, and small "islands", the small and medium-sized cities located in "submerged" territories, i.e., where there are circumstances of considerable depopulation and urban, economic and institutional decline' (2004, p. 296).

It is within this national framework that major old and new urban challenges are discussed here, considering five main topics covered by the New Urban Agenda assessment made by the United Nations HABITAT III Conference (Cavaco et al. 2016): urban demography; housing, basic services and urban planning; environment and urbanization; urban governance and legislation; and urban economy.

\subsection{Urban Demography: The Challenges of Litoralization and Metropolization}

Since 2000, the trend towards urban concentration of population has favoured the biggest urban agglomerations and the network of medium-sized cities to the detriment of smaller urban areas, and propelled migrations to coastal areas to the detriment of the interior of the country (Cavaco et al. 2014, 2016; MAOTE 2015). Nowadays, Portuguese cities are mostly medium sized, but with disparities in their geographic distribution and population size. Critical urban demographic challenges are now ageing, low birth rates, high emigration (particularly young people) and a recent increase of immigration (Cavaco et al. 2016). Solving the imbalances in the organization of densely populated regions and cities is also a main challenge for national urban policies (MAOTE 2015).

\subsection{Housing, Basic Services and Urban Planning: The Challenges of Urban Sprawl}

Following similar European trends, Portuguese urban areas have grown, particularly by means of suburbanization and urban sprawl. This has been 
associated with the increase of housing demand and the offering of large-scale infrastructure and commercial areas in the outskirts of urban centres. The built area per inhabitant rapidly became one of the highest in the EU, with a significant role for private and social housing (Fernandes and Seixas 2018). The urban housing context of today is characterized by the small size of the real estate rental market, the dominance of home ownership supported by credit loans, and the proliferation of construction and real estate marketing companies (Fernandes and Seixas 2018). In moving from a housing shortage at the beginning of the 1990s to today's housing surplus within a weak rental market and where housing costs are high, there have been consequences, not only in terms of 'urban sprawl, but also on the over-indebtedness of the country, the state, the enterprises and the families' (Cavaco et al. 2016). Urban rehabilitation and the improvement of peri-urban interfaces became strategic objectives and national goals (MAOTE 2015).

Furthermore, the spillover effects, which have led to the loss of both cultural heritage and natural assets as well as to the shrinkage and devitalization of urban cores (Cavaco et al. 2016), are a consequence of a 'triumph of the consumer society' and the abandonment of agriculture and rural areas (Fernandes and Seixas 2018).

The legal framework of spatial planning has evolved significantly since 1999, but a critical problem persists even today regarding the lack of regular monitoring on a national scale and of evaluation frameworks on the execution of both territorial management tools and public policies with territorial impacts.

\subsection{Environment and Urbanization: Challenging Sustainable Mobility and Climate Change Mitigation}

Along with the need to contain and consolidate urban perimeters, given that Portugal has one of the highest levels of built-up area per inhabitant in Europe, other actions were necessary, and therefore projects were undertaken to upgrade the sewerage networks in all the cities; to improve the water supply, both in terms of quantity and quality; and to significantly enhance digital infrastructures and education, health, sports and culture facilities (Fernandes and Seixas 2018). Changes in urban mobility patterns were also critical since the levels of motorization and the share of private cars increased severely, driven by the heavy investment in road infrastructure and the development model of the transportation system in Portugal (Sá Marques 2006; Cavaco et al. 2016). A coherent and sustainable transport policy has not been treated as a priority by the state (Cavaco et al. 2016).

Regarding climate change mitigation and adaptation, advances were made in the last decade, with urban policies being influenced by the National 
Programme for Climate Change (approved in 2004 and reviewed in 2006) and the National Strategy for Climate Change Adaptation (approved in 2010). Being an area that is relatively new to public administration, some difficulties are still being experienced concerning the lack of qualified human resources, financial support to adopt infrastructural measures, and the organization of services and tools integrated in strategies of a national, regional and local scope (Cavaco et al. 2016).

\subsection{Urban Governance and Legislation: Giving Progress a Sustaining Positive Impact}

The transfer of powers from the national government to local authorities and the reinforcement of local governments' autonomy, especially after 2005, brought many challenges and the need for urban governance. It required new planning and managing competences, greater technical, human and financial resources or capacities, and more effective interactions between local and central government (Cavaco 2018).

Nevertheless, this process of decentralization of competences towards the municipalities has not always been followed up by mechanisms to effectively ensure their accountability and transparency, as will be discussed in section 4 .

But the last two decades has witnessed an important period of progress towards a better legislation framework for spatial planning, sustainable development and urban development. Crucial revisions of legal and administrative frameworks have contributed to the harmonization at the national level of spatial planning procedures, the reorganization of the territorial management system and the promotion of urban rehabilitation under the principle of sustainable development (Sá Marques 2006; Cavaco et al. 2016). Nevertheless, the lack of stability and incoherence of legal frameworks, with a large number of revisions and amendments being made, still presents challenges for stronger integration and higher efficiency of spatial planning procedures (Cavaco et al. 2016; Cavaco 2018).

\subsection{Urban Economy: From Poverty Reduction to New Economic Challenges}

Income poverty and social exclusion in urban areas have been rising, along with the deterioration of housing conditions in core city centres, with impacts on the quality of life of the most vulnerable groups, namely the elderly, young people, women and emigrants (Cavaco et al. 2016). Problems of social and economic deprivation and vulnerability have assumed worrying proportions, particularly after 2010, at an individual, familiar and community level, 
especially in a context of lower incomes and higher unemployment rates that contribute to increase their incidence and intensity (Cavaco et al. 2016).

Tourism has been one of the key assets of the urban economy. In 2019, Portugal was ranked 12th in travel and tourism among 140 countries (Weforum 2019), with the number of yearly international tourists being higher than the Portuguese population. However, this tourism boom has brought critical challenges for the supply of local accommodation, challenges that have tended to multiply in city centres (Fernandes et al. 2019), resulting in gentrification, higher housing and living costs in some cities, and other problems such as noise or waste management. The role of culture, the creative industries and youth entrepreneurship has also had positive consequences in changing the local economic landscape (for example initiatives associated with graffiti, street art, urban art). Nevertheless, in terms of local finance, the majority of the municipalities are still in a delicate situation, after a period of excessive indebtedness followed by the economic crisis of 2008.

New economic challenges are now in place, and local governments are pursuing contemporary agendas. Programmes were created in order to foster innovation processes, knowledge-based economies and competitiveness strategies for urban systems, namely through Territorial Development Programmes.

\section{REVISITING 30 YEARS OF PUBLIC RESPONSES TO URBAN CHALLENGES}

Portugal's entry into the European Community is unanimously considered a milestone in the development of public policies focused on cities. However, before 1986 the Portuguese government had already undertaken initiatives aimed at solving urban problems, focused on the creation of regulations (for example 1977, Competências das Autarquias Locais |DL 79/77; 1979, Lei das Finanças Locais | Lei 1/79). Moreover, some innovative programmes were developed, such as the Serviço Ambulatório de Apoio Local (SAAL - Local Ambulatory Support Service), which established itself as a key tool in developing critical thinking and action related to housing problems in a context of political participation after the Carnation Revolution (Agarez 2018). Also in this context, Portugal established the first national programme aimed at supporting urban intervention - Programa de Reabilitação Urbana (PRU - Urban Rehabilitation Programme). This led to more coordinated practices between the central administration and the municipalities, and more local partnerships and private actions closer to the population (Pestana, Pinto-Leite and Marques 2009). The various initiatives, however, were not able to solve the housing problem in Portugal, nor overcome the disadvantages resulting from the unplanned urban expansion and the imbalances of the national urban system. 


\subsection{0s: Developing Policies for Urban Sustainability and Quality of Life}

If previous public concerns were mainly focused on housing problems and city centres, in the mid-1990s public instruments started to target territories other than the inner city and to address problems related to urban sprawl and imbalances in the national urban system. Programmes such as Programa Especial de Realojamento (PER - Special Rehousing Programme), Programa de Consolidação do Sistema Urbano Nacional e de Apoio à Execução dos PDMs (PROSIURB - Programme for the Consolidation of the National Urban System and Support for the Execution of Municipal Master Plans) and URBAN I were established in this period.

PROSIURB is particularly representative of this shift towards a logic not exclusively based on intra-urban intervention. The programme introduced a broader territorial perspective into the national urban policy discourse along with three innovative elements at that time: (i) the study, representation and analysis of prospective national urban system; (ii) the recognition of the importance of complementarity networks between cities and particularly between inland cities (aiming at strengthening critical mass); and (iii) the affirmation of the role of the 'city' in structuring its surrounding functional territory (Costa 1999).

At the international and European levels, the Rio Conference in 1992 along with the publication of the Green Paper on the Urban Environment (CCE 1990) and its translation into the concerns expressed in the European Commission's fifth Environment Programme (CCE 1993), were important for raising awareness on the quality of the urban environment and planning, as well as on sustainability. Additionally, two factors created the conditions for stimulating a critical awareness in Portuguese society of the quality of urban space: significant economic growth, which led to the improvement of living conditions, and the rehabilitation of the eastern part of the city of Lisbon in the context of the Lisbon World Exhibition - Expo 98.

The Plano Nacional de Desenvolvimento Económico e Social (PNDES - National Economic and Social Development Plan), implemented in 1998, reinforced the need to prioritize actions focused on the urban environment, directed, among others, towards improving the environmental and social quality of urban spaces. This plan introduced the need to intervene in the city in ways that go beyond simple urban management, by integrating environmental, sustainability and planning issues, and also suggesting the need for a strategic effort to redefine the role of each city within the new organization of the territory (Correia et al. 2000).

It was also during this decade that, under the URBAN I Community Initiative, Portugal developed programmes to support the revitalization and 
requalification of urban metropolitan areas with strong signs of economic, social, and environmental and physical degradation. This initiative placed great emphasis on the 'governance' dimension in programme preparation, with national and municipal authorities working closer together and reinforcing the role of local partnerships. However, implementation was marked by a lack of coordination resulting from insufficient strategic planning, notably in the formulation of metropolitan policies and the coordination of sectoral actions undertaken by the central state (Portas et al. 2004).

\subsection{0-2006: Implementing an Exemplary Programme of Urban Regeneration and Environmental Valorization}

The previous public policy instruments were not able to solve the major problems associated with urban sprawl. Linked problems, especially those related to the urban environment (for example traffic congestion; lack of quality of public spaces and green and leisure areas; degradation of the historical centres), together with the increased awareness of urban environmental sustainability issues, in line with international and European trends and guidelines, led the Portuguese government to recognize the need for an integrated city policy.

The most relevant national development plans during the period 2000-2006 focused on the regeneration of urban areas and their environmental quality as goals of strategic importance in improving cities' competitiveness, bolstering their role within the national urban system and enhancing the quality of life of their inhabitants. This is the case for the third National Regional Development Plan (III Plano de Desenvolvimento Regional) and the National Economic and Social Development Plan - Prospective View (Plano Nacional de Desenvolvimento Económico e Social - Visão Prospectiva) (MEPAT 1999).

Inspired by the experiences and best practices associated with the renovation of Lisbon in the context of Expo 98, the national government implemented the Programa de Requalificação Urbana e Valorização Ambiental das Cidades (POLIS - Urban Requalification and Environmental Enhancement of Cities Programme) (MAOT 2000). The purpose of this programme was not to resolve all urban and environmental problems in Portuguese cities (Partidário and Correia 2004), but to specifically focus on promoting urban requalification and environmental improvement (MAOT 2000).

This programme represented a significant change in urban intervention in Portugal, not only because of its innovative nature but also because of its results. It was anchored on some core principles: evidence-based policies; mobilization around the improvement of the urban environment; intervention in existing urban complexes to improve city liveability, and addressing citizens expectations; acknowledgement of and respect for social agents (Silva and Correia 2005). Moreover, POLIS adopted a 'complex and diversified' 
financial and governance structure (Partidário and Correia 2004, p. 416) based on multilevel governance between the central and local governments - but also considering the participation of other institutions and companies - and on shared costs (MAOT 2000; Partidário and Correia 2004). Some significant results have been highlighted in the literature, related to the Detailed Plans or Urbanization Plans that were produced, the traffic-restricted areas created, the distance covered by new cycling lanes, and the amount of green space made available (Queirós and Vale 2005).

POLIS was the embryo of national urban policy in Portugal (Pestana, Pinto-Leite and Marques 2009), which was later consolidated into the POLIS XXI Programme. European programmes such as URBAN II also had an important influence on the development of urban policies in Portugal during and after this period (Campos and Ferrão 2015).

\subsection{7-2013: Adopting for the First Time an Explicit Urban Agenda}

The legal framework of spatial planning evolved, and from 1999 onwards the Municipal Master Plans (PMOT) have been framed by supra-municipal plans of a programmatic and strategic nature, namely the National Spatial Development Policy Programme (first approved in 2007 and revised and published in 2018), Regional Spatial Development Plans (PROT) and the Regulatory Regime of Territorial Management Tools (RJIGT) (Cavaco et al. 2016).

For the first time, Portugal adopted an explicit urban agenda, coined Cities Policy - POLIS XXI (Politica de Cidades POLIS XXI). While recognizing the influence of several political initiatives and tools previously implemented (for example POLIS, PROSIURB, URBAN), this approach represented a shift in the way urban policies were conceived in Portugal. POLIS XXI assumed the commitment of "relaunching a strong and coherent "Cities Policy", coupled with innovative financing measures and appropriate models of territorial management and governance' (MAOTDR 2008, p. 1). Identifying weaknesses in the national urban system, and new and more complex urban challenges, the proposed policy framework was based on the interface between innovation and competitiveness, citizenship and social cohesion, quality of environment and quality of life, and planning and governance (MAOTDR 2008).

Innovation in POLIS XXI was mainly linked with three aspects: it expanded the intervention territories, being the city conceived in its intra-urban, inter-urban and city-region perspectives; it expanded the dimensions of intervention, to the benefit of a more integrative view of territorial development (for example physical, economic and social dimensions); and it introduced more participatory forms of governance and more flexible collaboration mech- 
anisms. This policy established a governance model based on the promotion of inter-municipal and local partnerships for the development of bottom-up strategies, supported by different levels of government, public and private partners, and local communities (MAOTDR 2008; Ribeiro 2012).

Policy implementation was supported by four programmes, translated into financing instruments: Parcerias para a Regeneração Urbana (PRU Partnerships for Urban Regeneration), Redes Urbanas para a Competitividade e a Inovação (RUCI - Urban Networks for Competitiveness and Innovation), Ações Inovadoras para o Desenvolvimento Urbano (AIDU - Innovative Actions for Urban Development) and Equipamentos Estruturantes do Sistema Urbano Nacional (Structuring Equipment of the National Urban System) (MAOTDR 2008).

Despite the robustness and scope of the policy framework introduced by POLIS XXI, which created high expectations in terms of its results (Barata Salgueiro, André and Brito-Henriques 2015), the outcomes failed to match these (Rosa 2018; Cavaco, Florentino and Pagliuso 2020). Several reasons for this, related to the operationalization of the policy and to adverse external factors, were pointed out by different authors. The difficulties in implementing the instruments (for example PRU) demonstrated the problems faced by local actors in interpreting POLIS XXI; the low institutional density of the partnerships, evidencing the weak involvement of local agents; and that the operative translation of the innovative nature of inter-municipal cooperation models (for example RUCI, AIDU) did not exactly correspond to its conceptual construction (Barata Salgueiro, André and Brito-Henriques 2015; Cavaco, Florentino and Pagliuso 2020; Rosa 2018).

In the context of POLIS XXI, and specifically under the Urban Regeneration Partnerships, and the Iniciativa Bairros Críticos (Critical Neighbourhoods Initiative), Portugal continued to approach deprived neighbourhoods and social-urban inclusion through the strengthening and support of the associated social fabric and the reversal of poverty and social exclusion cycles. Despite the relevance of those initiatives, their localized nature and lack of transversality undermined their potential wider urban impacts (Cavaco et al. 2016).

\subsection{4-2020: Is It Sustainable? The 'Sustainable Cities 2020' Strategy}

In Portugal, as in the EU context, the experience and knowledge generated during the previous EU programming cycle played a significant role in the urban policy strategy that was designed for 2014-2020. The strategic dimension assigned to cities and to sustainable development in trying to reach a more balanced national development are core policy priorities for this period. 
The strategy Sustainable Cities 2020 (DGT 2015) was the national response to explicitly promote sustainable urban development in Portugal, in line with supranational strategies. This strategy proposed guiding principles and a roadmap for city development, considering its different territorial dimensions - inter-urban, intra-urban and city-region (MAOTE 2015). Mostly addressed to public authorities intervening at the city level or at the national urban system level, it also considers the involvement of other local stakeholders as key in achieving sustainable development in a broad sense (MAOTE 2015). Additionally, multilevel coordination and the integration of different policy sectors are crucial elements of this strategy.

No operational funding tools were, however, directly linked to Sustainable Cities 2020. Financing and implementation of this strategy were framed by Portugal 2020, the EU Partnership Agreement for the 2014-2020 programming period, under the chapter 'integrated approach for territorial development in the application of the European Structural and Investment Funds' (Governo de Portugal 2014). In this context, different policy tools were developed in order to meet the EU-led policy initiatives, framed under different Thematic Operational Programmes (for example Competitiveness and Internationalization, Sustainability and Efficiency) and the five Regional Operational Programmes (NUTS II). These tools included Integrated Territorial Development (ITI) programmes, Community-Led Local Development (CLLD) initiatives and Integrated Actions for Sustainable Urban Development (IASUD) (MAOTE 2015; Rosa 2018). Responding to the requirement to create strategies and plans to benefit from public support, 23 Integrated Strategies for Territorial Development (EIDT, in the case of ITIs) and 105 Strategic Urban Development Plans (PEDU, in the case of IASUD) were created. The support of the Sustainable Cities 2020 strategy in Portugal was mainly concentrated in the two metropolitan areas (Lisbon and Porto), as well as in the 'higher-level cities' (10000-150000 inhabitants).

Although Portugal has adopted this explicit national strategy for sustainable urban development, some authors question its real national urban policy nature. Some mention its lack of effectiveness (Cavaco, Florentino and Pagliuso 2020); others the existence of a fragmented urban agenda, which only responds to specific aspects of supranational agendas and to European programmes and public funding (Ferrão 2018). Several aspects associated with the operationalization of the strategy have been identified as factors that weaken it. Among these is the fact that national strategy was elaborated by the Ministry of Environment and Spatial Development but the allocation of ESIF for ISUD approaches was designed by a different Ministry (Ministry of Regional Development), with little coordination between them. Moreover, the complexity and fragmentation of funding mechanisms (each often requiring a different set of strategy documents and action plans) make it problematic 
to scrutinize and to implement in a coherent way (Cavaco, Florentino and Pagliuso 2020; Rosa 2018).

Furthermore, specific characteristics of the Portuguese political structure do not favour the greater autonomy and proactivity of cities needed to deal with current challenges, which will be discussed in the next section.

\section{ACTORS AND MULTILEVEL GOVERNANCE IN URBAN POLICIES}

In such a centralized country as Portugal (Teles 2012, 2014), which lacks a directly elected body at an intermediate level between the central government and the municipality, urban policies have been understood as a sub-product of national incentives, general policies and mandatory regulations. Even though the autonomy of local authorities allows for some degree of policy discretion (Ladner et al. 2019), their action requires a negotiated consensus over time between governance actors. The efficient delivery of urban policies is, therefore, a consequence of multilevel governance capacity, where the ability of political actors to gather the relevant tools and to negotiate policies between tiers of government is necessary for taking collective action. Evidently, the robustness of these processes of alliance building hinges on their perceived legitimacy, and the consistency of such arrangements is highly dependent on their stability and on the commitment between actors. The existence of a national association of municipalities, which could play an important role in the articulation of the interests of cities, does not mean that there is a recognized mechanism to overcome and address these problems. In fact, the association is not a powerful player, nor one focused specifically on urban policies, given the multiple broader interests of municipalities.

Ultimately, the abovementioned challenges and policies related to how urban areas should be governed are inherently linked to ongoing processes of multilevel governance, with questions that remain unanswered related to efficiency and stability. Both their fragility over time and the clear change in pattern of societal and economic challenges to address, as well as of institutional and financial incentives put in place, creates significant imbalances within the multilevel arrangements. As a consequence of this setting, the first challenge of urban policies in Portugal is precisely the fact that they are unlikely to persist over time and, in most cases, they may result in a deterioration of the overall governance capacity between policy cycles.

The second challenge results from the change in actors involved in multilevel governance, particularly given the two concomitant processes that accompanied urban policies during the last decades in Portugal: consolidation of democracy and decentralization. Both have led to an evolution in formal government structures at the national, regional and local level, together with 
a change in competencies and autonomy. Urban policies require an adequate response which demands the design of effective territorial arrangements, with clear and stable policy instruments and scope of action. However, the period under consideration in this chapter is precisely the one when these structures of multilevel governance were under significant and evolutive change. Consequently, and in other words, the aim to maximize urban policy efficiency did not meet with an adequate answer from these local actors, since local governments were under pressure to cope with other demands for governance capacity and were receiving incentives to strengthen their competencies and autonomy.

The challenges of urban governance also emphasize scale and capacity problems with local authorities. In fact, all the differences and imbalances between different urban authorities in Portugal, with clear asymmetries in government structures, governance arrangements and institutional capacity, amplify these problems. In urban policy, local authorities are more than just service providers and require an adequate design of effective territorial arrangements, which entails obvious pressures over multilevel policy articulation and power relations. Power over policy-making requires a wide range of mechanisms. The multilevel context underlines the need to implement an adequate approach to service restructuring, modernization agendas and public administration reforms. There is no evidence that would confirm that all these reforms took into consideration the need to address the urban policy agenda in Portugal.

Instability, weak governance capacity, unbalanced structures and non-concurring policies are the main features of the broader picture just presented. It clearly underlines obstacles with multilevel governance in urban policies in Portugal and may explain most of the drawbacks and policy uncertainty examples presented in this chapter. This has resulted in unresolved situations related to the differentiation and integration of policy actors in the implementation of urban policies.

The needed articulation between tiers of government in a mutual shaping process of policies has practical implications for the actors engaged and for the governance arrangement design. It seems obvious that an argument in favour of a multilevel approach to urban policies, which in fact is present in the framework of all the mentioned policies in the previous sections of this chapter, is deeply connected with a stable, capable and efficiency-focused multilevel arrangement. However, these are precisely the challenges that Portugal has faced during the last decades, where sub-national authorities are immersed in unpredictable, diverse and governance-volatile contexts.

Urban policy efficiency presupposes a rather well institutionalized and stable multilevel landscape, allowing for the establishment of policy coalitions and their maintenance. In fact, urban policy-making and delivery is not always 
solely dependent on local actors. Their embeddedness within a broader governance context (regional authorities, national urban policies, EU programmes and incentives) brings dynamism into the policy process and requires all actors to avoid the scale trap, which would lead each of them to a biased approach to their role in urban policies.

\section{CONCLUDING REMARKS}

From the building of democracy, since the Carnation Revolution in 1974, until the accession to the European Economic Community (EEC) in 1986, Portugal experienced political instability and major social changes. The period after 1986 was noticeably influenced by EU policies, institutional structures and funds, and represents a time of greater structural change in the country (1986-2000), the changes then being consolidated in the following phase running from 2000 until the economic crisis of 2008. Joining the European Community allowed Portugal access to funds, methodologies and guidelines, which had a positive influence on the expansion of public investment, on the consolidation of the legal framework of the planning system, and on territorial and urban infrastructure.

The most recent decade is characterized by the establishment of new strategies and policies addressing major urban challenges, namely related to urban demography; housing, basic services and urban planning; environment and urbanization; urban governance and legislation; and urban economy.

Although the current national urban policy framework is the result of a path characterized by advances and setbacks, with some key elements of a national urban policy remaining to be developed and consolidated, progress has been made in programmes, tools, capacity building and mutual learning.

Public concerns about urban territories have evolved from a perspective focused on the creation of plans and regulations, as well as physical interventions centred on intra-urban spaces, to one where strategic formulation and management aspects play a key role. Nowadays, urban policies are more flexible, integrated and strategic, and advocate cooperation between different types of actors, including citizens, and creativity in finding solutions to major urban challenges. The concepts used in d'Albergo's typology (see Chapter 1 in this book) are useful to provide a broader picture of this evolution in urban policies in Portugal: from implicit and indirect policies, to the recent years with explicit and direct actions and programmes.

Although consensus exists in recognizing the significant changes that have occurred in Portugal regarding urban policies (programmes, tools, capacity building, knowledge), some authors question the existence of a real national urban policy (for example Ferrão 2018). In addition, the specific challenges of the multilevel governance character of urban policies may have led Portugal to 
an unbalanced situation, where relevant questions need to be tackled regarding multilevel governance stability, capacity and efficiency of policy arrangements, especially to enforce a stronger national learning and coordination between different urban policy strategies in Portuguese cities.

\section{REFERENCES}

Agarez, R.C. (2018), Habitação. Cem anos de políticas públicas em Portugal 1918-2018, Lisbon: Imprensa Nacional-Casa da Moeda.

Barata Salgueiro, T., I. André and E. Brito-Henriques (2015), 'A Política de Cidades em Portugal: instrumentos, realizações e perspectivas', in P. Neto and M.M. Serrano (eds), Políticas Públicas, Economia e Sociedade. Contributos para a definição de políticas no período 2014-2020, Alcochete: Smartbook, pp. 49-82.

Campos, V. and J. Ferrão (2015), 'O Ordenamento do território: uma perspectiva genealógica', ICS Working Papers, 1 (2015), accessed 16 June 2020 at http://www.ics.ul .pt/flipping/wp2015_1/index.html.

Cavaco, C. (2018), 'Ūrbanismo como política pública: que mudanças de azimute?', Território, Planeamento e Urbanismo. Teoria e Prática, no. 1, 78-104.

Cavaco, C., R. Florentino and A. Pagliuso (2020), 'Urban policies in Portugal', in S. Armondi and S. De Gregorio Hurtado (eds), Foregrounding Urban Agendas: The New Urban Issue in European Experiences of Policy-Making, Cham: Springer, pp. 49-73.

Cavaco, C., A.G. Oliveira, C. Gusmão, M. Castelo Branco, M. Nicolau, M. da L. França, M. do R. Gaspar (2016), Habitat III - Relatório Nacional Portugal, Lisbon: Direção-Geral do Território.

Cavaco, C., E. Vilares, A. Oliveira, C. Barbosa, C. Gusmão, L. Pedroso and M. Nicolau (2014), Avaliação Do Programa Nacional Da Política de Ordenamento Do Território, Lisbon: Direção-Geral do Território.

CCE (1990), 'Green Paper on the Urban Environment', COM (90) 218 final, Brussels: EU Commission, 27 June.

CCE (1993), Towards Sustainability: A European Community Programme of Policy and Action in Relation to the Environment and Sustainable Development (The Fifth EC Environmental Action Programme), Official Journal of the European Communities, No C 138/7, Brussels: EU Commission.

Correia, F.N., J.B. Cruz, R.B. Martins, P. Liberato and L. Morbey (2000), Programa de Requalificação Urbana e Valorização Ambiental de Cidades, Lisbon: Ministério do Ambiente e do Ordenamento do Território.

Costa, E.M. da (1999), 'Uma nota sobre as políticas das cidades em Portugal nos anos noventa', Inforgeo, 14, 131-137.

DGT (2015), Cidades Sustentáveis 2020, Lisbon: Direcção Geral do Território.

Fernandes, J.A.R., P. Chamusca, T. Mendes and L. Carvalho (2019), A Airbnb em Portugal, Lisbon: Book Cover Editora.

Fernandes, J.A.R. and J. Seixas (2018), 'Cities and urbanisation in democratic Portugal', Méditerranée, 130. DOI:10.4000/mediterranee.10698.

Ferrão, J. (2018), 'Novas Agendas Urbanas: Que Desafios para o Ordenamento do Território?', paper presented at Congresso Ibérico Direito do Urbanismo, 'O Direito e a prática urbanística na Península Ibérica: Desafios da Nova Agenda Urbana da União Europeia', Faculdade de Direito da Universidade de Lisboa, Lisbon, 16 March 2018. 
Governo de Portugal (2014), Portugal 2020 - Partnership Agreement 2014-2020, Governo de Portugal.

INE (2019), Estatísticas Demográficas - 2018, Lisbon: Instituto Nacional de Estatística.

Ladner, A., N. Keuffer, H. Baldersheim, N. Hlepas, P. Swianiewicz, K. Steyvers and C. Navarro (2019), Patterns of Local Autonomy in Europe, Basingstoke: Palgrave Macmillan.

MAOT (2000), Programa Polis - Programa de Requalificação Urbana e Valorização Ambiental das Cidades, Lisbon: Ministério do Ambiente e do Ordenamento do Território.

MAOTDR (2008), Portugal Política de Cidades. POLIS XXI 2007-2013, Lisbon: Ministério do Ambiente, do Ordenamento do Território e do Desenvolvimento Regional.

MAOTE (2015), Cidades Sustentáveis 2020. Diagnóstico Territorial, Lisbon: DG Territorio.

MEPAT (1999), Plano Nacional de Desenvolvimento Económico e Social - Visão Prospectiva, Lisbon: Ministério do Equipamento e da Administração do Território.

Partidário, M.D.R. and F.N. Correia (2004), 'Polis - the Portuguese programme on urban environment. A contribution to the discussion on European Urban Policy', European Planning Studies, 12 (3), 409-423.

Pestana, C., J. Pinto-Leite and N. Marques (2009), 'O Programa Polis como impulsionador da regeneração urbana', $15 .{ }^{\circ}$ Congresso da APDR, Cidade da Praia: APDR.

PORDATA (2018), 'Ageing index', accessed 16 June 2020 at https://www.pordata.pt/ en/Europe/Ageing+index-1609.

Portas, N., A. Domingues and A.L. Guimarães (2004), 'Portugal', in L. Van der Berg, E. Braun and J. Van der Meer (eds), National Urban Policies in the European Union: Responses to Urban Issues in the Fifteen Member States, Aldershot: Ashgate, pp. 290-324.

Queirós, M. and M. Vale (2005), 'Ambiente Urbano e Intervenção Pública: O Programa POLIS', X Colóquio Iberico de Geografia 'A Geografia Ibérica no Contexto Europeu', Universidade de Évora, 22/24-9-2005, accessed 30 May 2020 at http://www.apgeo.pt/files/docs/CD_X_Coloquio_Iberico_Geografia/pdfs/047.pdf.

Ribeiro, P.C.S. (2012), A avaliação dās políticas dē regeneração urbana em contextos intraurbanos, Porto: Universidade do Porto.

Rosa, F. (2018), 'O Desenvolvimento Urbano Sustentável na Política de Coesão', Coleção Políticas and Territórios, Working Paper No. 02.

Sá Marques, T. (2006), 'Portugal Urbano: Mosaicos, Polaridades, Relacionamentos, Governança', in A. Domingues (ed.), Cidade e Democracia: 30 anos de Transformação Urbana em Portugal, Lisbon: Argumentum, pp. 80-91.

Silva, M.S. and F.N. Correia (2005), 'Uma nova forma de viver as cidades - O exemplo demonstrativo do Polis', Sociedade e Território, 39, 32-43.

Tavares, A. and F. Teles (2018), 'Deeply rooted but still striving for a role: the Portuguese Freguesias under reform', in N. Hlepas, N. Kersting, S. Kuhlmann, P. Swianiewicz and F. Teles (eds), Sub-municipal Governance in Europe: In Search of Expressive and Responsive Communities?, Basingstoke: Palgrave Macmillan, pp. 193-209.

Teles, F. (2012), 'Beyond paternalism towards social capital: local governance reform in Portugal', International Journal of Public Administration, 35 (13), 864-872.

Teles, F. (2014), 'Local government and the bailout: reform singularities in Portugal', European Urban and Regional Studies, 23 (3), 455-467. 
Weforum (2019), The Travel and Tourism Competitiveness Report 2019: Travel and Tourism at a Tipping Point, Geneva: World Economic Forum Insight Report. 